\section{Indian zoologist suspected}

\section{New Delhi}

A researcher at Bharatiyar University in the south of India is being investigated by the university for a deception allegedly practised on his British and US colleagues during scientific visits last summer. Professor G. Sundara Rajulu, head of the zoology department at Bharatiyar, has been accused by two US scientists of having 'perpetrated a hoax' by pretending that blood samples he collected in Britain came from a rare worm he claimed to have found in India.

The allegations were made in a letter written on 10 October to the chancellor of Bharatiyar University by Joseph Bonaventura, director of the marine biomedical centre at Duke University, North Carolina, and Charlotte Mangum, professor of biology at the College of William and Mary in Williamsburg, Virginia. Rajulu had spent two weeks as a guest in their laboratories during May and June.

The affair began when Rajulu contacted Bonaventura and Mangum, claiming that he had found haemocyanin, the copper-containing analogue of haemoglobin, in the rare Himalayan species Eoperipatus Weldoni a member of the phylum Onycophora. He wanted to bring some samples to the United States for further analysis. Onycophora are thought to be a link between annelid (legless) worms and arthropods, and the presence of haemocyanin could shed light on the link. Bonaventura and Mangum invited Rajulu to bring some live specimens to the United States for further analysis.

But when he reached their laboratories, Rajulu had no live specimens, and said they had been confiscated by US customs officials. Instead he produced a frozen blood sample and a preserved specimen of what he claimed was E. Weldoni.

The blood sample did indeed contain a haemocyanin typical of crustaceans, but on further examination turned out to have a general composition more characteristic of marine than land organisms. Mangum then discovered that Rajulu had come to the United States after a visit to Muriel Walker at the University of Leicester in England. An exchange of letters with Walker revealed not only that the blood sample Rajulu took to the United States was from a British shore crab, but also that he had told his UK hosts the same story about confiscated specimens that he had related to Bonaventura and Mangum.

Rajulu was supposed to have brought to Walker and her colleague Robert Harris live specimens of some other Himalayan creatures, but said that UK customs officials had confiscated all but one partial sample, which Harris later ascertained to be part of a common marine worm. The blood sample that Rajulu presented to
Bonaventura and Mangum was collected at his request by Harris.

Rajulu admits he has been served with an "explanation notice" by Bharatiyar University, but is surprised at the fraud allegation because, he says, Bonaventura and Mangum expressed no doubts about his discovery of haemocyanin during his visit to their laboratories. But on 26 July, after he had gone back to India, Rajulu sent Bonaventura a brief note saying that "in my anxiety to do things I committed a lot of mistakes" and apologizing for the

\section{Tokyo}

JAPAN's hospitals and doctors are reaping enormous profits through sales of prescription drugs because pharmaceutical companies sell the drugs to medical professionals at a price far below the government's official reimbursement prices, an official of the Ministry of Health and Welfare admitted in the Diet earlier this month. The discounting practice has long been known to exist and is a major driving force behind excessive consumption of prescription drugs in Japan. But it is the first time a government official has put a figure on drug profiteering.

During a session of the auditing committee of the House of Representatives on 8 November, Tatsuhiko Sakamoto, director-general of the Health Insurance Bureau of the Ministry of Health and Welfare, under questioning by a member of the opposition Komeito party, revealed that the profits amount to about $¥ 1.3$ million million (nearly $\$ 10,000$ million) per year. Medical institutions charged patients and the health insurance system about $¥ 5.15$ million million yen for drugs in 1987 on basis of the ministry's official prices, but Sakamoto estimates the actual cost to the institutions to be only $¥ 3.83$ million million.

Unlike medical practice in most developed nations where doctors are not allowed to sell drugs, nearly all hospitals and general practitioners in Japan have their own in-house pharmacies. To promote sales, pharmaceutical companies sell drugs to medical institutions at below the government's official price (the price that determines charges). There is thus a strong incentive for doctors to overprescribe and to prescribe drugs unnecessarily because they make a profit on every sale.

The profiteering and overprescription is a massive drain on the national health system and also has serious consequences for the health of the nation.

One example is antibiotics. In the West, doctors try to avoid prescription of anti- matter. But no other explanation of the incidents was offered.

The Indian National Science Academy has also been sent a copy of the allegations but has yet to take any action. Bonaventura and Mangum agree that no great damage was done by the incident, apart from the waste of several researchers' time, but want to have the matter investigated because Rajulu is in the habit of arranging annual scientific visits outside India. Mangum says she knows of trips to Korea, Belgium and Vancouver, but has had no success in discovering if any similar deceptions occurred on those trips.

K.S. Jayaraman

\title{
Huge profit from drugs
}

biotics because of the risk of development of antibiotic-resistant bacteria. But in Japan, antibiotics are liberally prescribed for all sorts of minor infections.

Another example is blood products. In the early 1980s, consumption in Japan surged with the import from the United States of cheap blood products which companies then sold to medical institutions at well below the government's official price. Among them were blood coagulants infected with AIDS, and most of Japan's 1,000 or so AIDS patients and carriers of the virus are haemophiliacs infected by the imported products.

For years, the ministry has been trying to separate the dispensing of drugs from doctors (a process called bungyo in Japanese). One approach has been to encourage the use of so-called 'legal prescriptions' which are handled by pharmacies outside the hospital. In response, large numbers of 'second pharmacies' have sprung up although at first sight independent, they are in fact linked to medical practitioners. The doctor's wife, for example, may own the pharmacy.

Doctors and hospitals maintain that profits from drug sales are essential for management of their institutions. But slowly they are being brought 'reluctantly' towards full-scale bungyo, says Luke Gander of Pharma Japan, a newsletter for the pharmaceutical industry. But Gandor does not expect complete separation of doctors and pharmacies for 10 to 15 years.

There are too many vested interests to bring about rapid change. Pharmaceutical companies, both foreign and Japanese, are happy with their high sales in Japan. Doctors are happy with their profits. And the unquestioning Japanese public are happy to take home their bagfuls of unlabelled drugs after they visit the doctor. As the representative of one British pharmaceutical company observed, "It doesn't seem to do them any harm. The Japanese have the highest life expectancy in the world."

David Swinbanks 